\title{
Delimiting the genera of the Ficinia Clade (Cypereae, Cyperaceae) based on molecular phylogenetic data
}

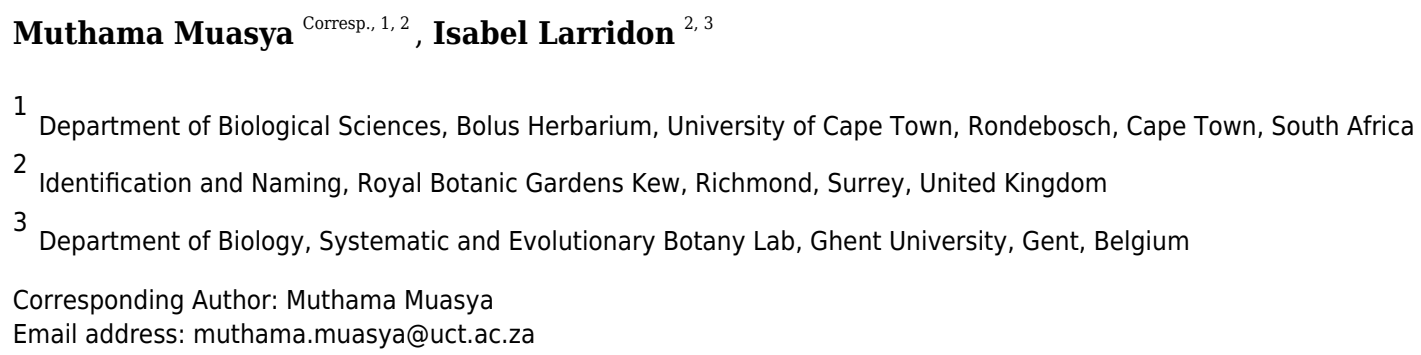

Generic delimitations in the Ficinia Clade of tribe Cypereae are revisited. In particular, we aim to establish the placement of annual species currently included in Isolepis of which the phylogenetic position is uncertain. Phylogenetic inference is based on two nuclear markers (ETS, ITS) and five plastid markers (the genes matK, ndhF, rbcL and rps16, the trnL intron and $t r n L-F$ spacer) data, analyzed using model based methods. Topologies based on nuclear and plastid data show incongruence at the backbone. Therefore, the results are presented separately. The monophyly of the smaller genera (Afroscirpoides, Dracoscirpoides, Erioscirpus, Hellmuthia, Scirpoides) is confirmed. However, Isolepis is paraphyletic as Ficinia is retrieved as one of its clades. Furthermore, Ficinia is paraphyletic if $I$. marginata and allies are excluded. We take a pragmatic approach based on the nuclear topology, driven by a desire to minimize taxonomic changes, to recircumscribe Ficinia to include the annual Isolepis species characterized by cartilaginous glumes and formally include all the Isolepis species inferred outside the core Isolepis clade.

Consequently, the circumscription of Isolepis is narrowed to encompass only those species retrieved as part of the core Isolepis clade. Five new combinations are made (Ficinia capensis, Ficinia heminucialis, Ficinia incomtula, Ficinia leucoloma, Ficinia minuta). We present nomenclatural summary at genus level, identification keys and diagnostic features. 
1 Delimiting the genera of the Ficinia Clade (Cypereae, 2 Cyperaceae) based on molecular phylogenetic data

3

4

5

6

7

8

\author{
A. Muthama Muasya ${ }^{1,2}$, Isabel Larridon ${ }^{2,3}$ \\ ${ }^{1}$ Bolus Herbarium, Department of Biological Sciences, University of Cape Town, Rondebosch, \\ Cape Town, South Africa \\ 2 Identification and Naming, Royal Botanic Gardens Kew, Richmond, Surrey, United Kingdom \\ ${ }^{3}$ Department of Biology, Systematic and Evolutionary Botany Lab, Ghent University, Gent, \\ Belgium
}

Corresponding Author:

Muthama Muasya ${ }^{1}$

Department of Biological Sciences, Bolus Herbarium, University of Cape Town, Rondebosch, Cape Town, South Africa

Email address: muthama.muasya@uct.ac.za

\title{
Abstract
}

Generic delimitations in the Ficinia Clade of tribe Cypereae are revisited. In particular, we aim to establish the placement of annual species currently included in Isolepis of which the phylogenetic position is uncertain. Phylogenetic inference is based on two nuclear markers (ETS, ITS) and five plastid markers (the genes $m a t K, n d h F, r b c L$ and $r p s 16$, the $\operatorname{trn} L$ intron and $t r n L-F$ spacer) data, analyzed using model based methods. Topologies based on nuclear and plastid data show incongruence at the backbone. Therefore, the results are presented separately. The monophyly of the smaller genera (Afroscirpoides, Dracoscirpoides, Erioscirpus, Hellmuthia, Scirpoides) is confirmed. However, Isolepis is paraphyletic as Ficinia is retrieved as one of its clades. Furthermore, Ficinia is paraphyletic if I. marginata and allies are excluded. We take a pragmatic approach based on the nuclear topology, driven by a desire to minimize taxonomic changes, to recircumscribe Ficinia to include the annual Isolepis species characterized by cartilaginous glumes and formally include all the Isolepis species inferred outside the core Isolepis clade. Consequently, the circumscription of Isolepis is narrowed to encompass only those species retrieved as part of the core Isolepis clade. Five new combinations are made (Ficinia capensis, Ficinia heminucialis, Ficinia incomtula, Ficinia leucoloma, Ficinia minuta). We present nomenclatural summary at genus level, identification keys and diagnostic features.

\section{Introduction}

The paradigm shift towards recognition of genera as monophyletic entities has necessitated changes in generic circumscription (Humphries \& Linder, 2009). Within Cyperaceae, a number 
40 of changes have been made within the last decade, for example the merger of segregate genera 41 into the paraphyletic core in Carex L. (GCG, 2015) and Cyperus L. (Larridon et al., 2011a, b, 42 2013, 2014; Bauters et al., 2014). A number of genera have been found to be polyphyletic, 43 especially in the tribe Schoeneae, resolved by reclassification of entities and naming of a number 44 of lineages as new genera (e.g. Elliott \& Muasya, 2017; Larridon et al., 2018a, b; Barrett et al., 45 2019). Each of the four Cyperaceae genera recognized by Linnaeus (1753) has been reclassified 46 over the years, with Linnaeus' circumscription of Scirpus L. as encompassing species with 47 bisexual flowers and spiral glume arrangement representing the most heterogenous assemblage. 48 Embryo morphology data (Van der Veken, 1965; Goetghebeur, 1986; Semmouri et al., 2019) 49 have unequivocally demonstrated that lineages with distinct morphology were included in Scirpus. In his seminal treatment of the family, Goetghebeur (1998) placed the 24 taxa previously named Scirpus by Linnaeus (1753) in the tribes Cypereae, Fuireneae and Scirpeae, with $S$. sylvaticus L. being the only species described by Linnaeus recognized as a true Scirpus and two of the species recognized as members of Isolepis R.Br.

Within tribe Cypereae, the Ficinia Clade (sensu Muasya et al., 2009a) comprises taxa whose placement has been most contentious. Goetghebeur (1998) diagnosed tribe Cypereae to include species characterised by either a Cyperus or a Ficinia type embryo, where glumes are arranged distichously (Cyperus and allies) or spirally (Isolepis, Ficinia Schrad., Scirpoides Ség). Lineages bearing perianth segments were added to the clade based on molecular phylogenetic data, moving Hellmuthia Steud. from Chysitricheae (Vrijdaghs et al., 2006; Muasya et al., 2009a, b), Erioscirpus Palla from Scirpeae (Yano et al., 2012), and recognizing southern African taxa previously placed in Scirpus as a distinct genus Dracoscirpoides Muasya (Muasya et al., 2012). Furthermore, the delimitation of Scirpoides has been altered to exclude Afroscirpoides GarcíaMadr. \& Muasya (García-Madrid et al., 2015) and the addition of two species that were ambiguously placed (Browning \& Gordon Gray, 2011; Reid et al., 2017). These genera are annual to perennial herbs, have basal leaves which vary in blade development, have considerable variation in inflorescence and floral morphology, and are diagnosed by a combination of morphological features (see Table 2 in García-Madrid et al., 2015).

69

70

71

72

73

74

75

76

77

78

79

Generic delimitation between Isolepis and Ficinia is based on few morphological characters. Isolepis have a varied habit (annual to perennial) and are widespread, whereas Ficinia are perennial and predominantly occur within the Cape flora and in Africa (Goetghebeur, 1998; Muasya \& Simpson, 2002). A further distinction is the presence of a gynophore in Ficinia, but several species having a gynophore and occurring outside Africa were previously excluded from the genus. For example, the New Zealand iconic sand dune taxon (Desmoschoenus spiralis (A.Rich.) Hook.f.) is embedded within core Ficinia (as Ficinia spiralis (A.Rich.) Muasya \& de Lange; Muasya \& de Lange, 2010), and the more widespread Ficinia nodosa (Rottb.) Goetgh., Muasya \& D.A.Simpson was retained in Isolepis despite having a well developed gynophore (Muasya et al., 2000). Furthermore, Isolepis may not be monophyletic as Ficinia is one of the 
80 three to four clades recovered in Isolepis (Muasya \& de Lange, 2010; Garcia-Madrid et al., 81 2015; Hinchcliff \& Roalson, 2013; Spalink et al., 2016; Semmouri et al., 2019). Challenges on 82 distinguishing Ficinia from Isolepis have persisted over the last 200 years, as evident from at 83 least one in six of the currently recognized Ficinia species having a validly published epithet in 84 Isolepis (Govaerts et al., 2020).

85

86

87

88

89

90

91

92

93

94

95

96

97

98

99

100

101

102

103

104

105

106

107

108

109

110

111

112

113

114

115

116

117

118

119

We use an expanded molecular phylogenetic study to investigate the generic limits in the Ficinia Clade. We infer the phylogenetic relationships and placement of ambiguously placed Isolepis species, namely (1) I. hemiuncialis (C.B.Clarke) J.Raynal and I. incomtula Nees - which have been previously recovered as sister to the core Isolepis/Ficinia clade; (2) I. marginata (Thunb.) A.Dietr. and allies (I. antarctica (L.) Roem. \& Schult., I. capensis Muasya, I. leucoloma (Nees) C.Archer, I. minuta (Turrill) J.Raynal). - previously recovered as sister to core clade of Ficinia. The aim is to establish whether the genera in the Ficinia Clade, particularly Isolepis and Ficinia, are monophyletic, and to evaluate what characters diagnose the inferred (sub)clades.

\section{Materials \& Methods}

\section{Ethics statement}

Part of the specimens studied were collected during field expeditions predominantly in Western Cape province of South Africa funded by grants from the National Research Foundation and with additional support from the University of Cape Town. Permit to collect these specimens were issued by the Cape Nature authorities (CN35-28-5831). The other specimens studied are available in publicly accessible herbaria (BOL, K; Thiers, continuously updated) and voucher details provided in Supplementary information (Table S1, S2).

\section{Nomenclature and taxonomy}

A nomenclatural study including the taxonomic history of the genus and its species, critical for the correct coining of the new names and the proper use of prior ones, was performed. The electronic version of this article in Portable Document Format (PDF) will represent a published work according to the International Code of Nomenclature for algae, fungi, and plants (ICN), and hence the new names contained in the electronic version are effectively published under that Code from the electronic edition alone. In addition, new names contained in this work which have been issued with identifiers by IPNI will eventually be made available to the Global Names Index. The IPNI LSIDs can be resolved and the associated information viewed through any standard web browser by appending the LSID contained in this publication to the prefix "http://ipni.org/". The online version of this work is archived and available from the following digital repositories: PeerJ, PubMed Central, and CLOCKSS.

\section{Molecular study}

The Ficinia Clade, our focus group, includes the genera Afroscirpoides (1 species), Dracoscripoides (3 species), Erioscirpus (2 species), Ficinia (81 species), Hellmuthia (1 
120

121

122

123

124

125

126

127

128

129

130

131

132

133

134

135

136

137

138

139

140

141

142

143

144

145

146

147

148

149

150

151

152

153

154

155

156

157

158

species), Isolepis (75 species) and Scirpoides (4 species). A total of 166 ingroup accessions were sequenced (Table S1), representing: 1 species of Afroscirpoides (100\%), 3 Dracoscripoides (100 \%), 1 Erioscirpus (50\%), 64 (plus 3 undescribed) Ficinia (78 \%), 1 Hellmuthia (100\%), 57 Isolepis (plus some infraspecific taxa) (76\%) and 3 Scirpoides (75\%). The outgroup taxa, selected based on Semmouri et al. (2019) and Larridon et al. (in review), consists of 114 accession (Table S2) representing the six genera of tribe Fuireneae and the genus Cyperus, the only genus of the Cyperus Clade of tribe Cypereae after Androtrichum was recently synonymysed with Cyperus (Pereira-Silva et al., 2020). The DNA extraction protocol, primers, and material and methods for PCR amplification and sequencing follow Viljoen et al., 2013.

Sequences were assembled and edited in Geneious R8 (http://www.geneious.com, Kearse et al., 2012), aligned using MAFFT 7 (Katoh et al., 2009; Katoh \& Standley, 2013) with 'maxiterate' and 'tree rebuilding number' set to 100 (long run), afterwards, alignments were checked manually in PhyDE 0.9971 (Müller et al., 2010).

We first inferred the gene trees for each of the regions separately to identify potential incongruence. As there were no instances of conflict at well-supported nodes between the two nuclear markers, and between the five chloroplast makers, the matrices of the regions were concatenated into a nuclear dataset (Data S1) including ETS and ITS, and in a chloroplast dataset (Data S2) including the genes $m a t K, n d h F, r b c L$ and $r p s 16$, the $\operatorname{trnL}$ intron and $t r n L-F$ spacer for the downstream analyses. PartitionFinder 2.1.1 (Lanfear et al., 2012) was used to determine an appropriate data-partitioning scheme from potential partitions that were defined a priori (in this case, each marker was treated as a separate partition), as well as the best-fitting model of molecular evolution for each partition, using the Bayesian Information Criterion. For the nuclear dataset, PartitionFinder confirmed the a priori data-partitioning scheme, and the GTR $+\mathrm{I}+\Gamma$ (invgamma) model of sequence evolution was determined to be the best-fitting model for the two nrDNA markers. For the chloroplast dataset, PartitionFinder suggested partitioning the data in four partitions ( $m a t K+r p s 16, n d h F, r b c L$, the $t r n L$ intron and $t r n L-F$ spacer), and the GTR $+\Gamma$ (gamma) model of sequence evolution was determined to be the best-fitting model for all partitions except for $r b c L$ for which the GTR $+\mathrm{I}+\Gamma$ (invgamma) model was suggested.

Maximum likelihood (ML) analyses of the optimally partitioned data were performed using RAxML 8.2.10 (Stamatakis, 2014). The search for an optimal ML tree was combined with a rapid bootstrap analysis of 1000 replicates. Additionally, partitioned analyses were conducted using Bayesian Inference (BI) in MrBayes 3.2.6 (Ronquist et al., 2012). Rate heterogeneity, base frequencies, and substitution rates across partitions were unlinked. The analysis was allowed to run for 100 million generations across two independent runs with four chains each, sampling every 10,000 generations. Convergence, associated likelihood values, effective sample size (ESS) values and burn-in values of the different runs were verified with Tracer 1.5 (Rambaut \& Drummond, 2007). The first $25 \%$ of the trees from all runs were excluded as burn-in before making a majority-rule consensus of the posterior distribution trees using the "sumt" function. All phylogenetic analyses were run using the CIPRES portal (http://www.phylo.org/; Miller et 
159

160

161

162

163

164

165

166

167

168

169

170

171

172

173

174

175

176

177

178

179

180

181

182

183

184

185

186

187

188

189

190

191

192

193

194

195

196

197

198

199

al., 2011), and were executed for both full and reduced sampling alignments. Trees were drawn using TreeGraph2 (Stöver \& Müller, 2010).

\section{Morphological study}

Herbarium specimens of BOL, BR, GENT, K, NBG, PRE (Thiers, continuously updated) were studied morphologically using a Leica (Leica Microsystems, Wetzlar, Germany) binocular microscope. Measurements where made with a ruler and digital calipers (e.g. leaf and culm length), or using a binocular microscope with graticule (e.g. spikelet and glume length). When examining width, this was done near the middle of the organ (e.g. middle of the nutlet).

\section{Results}

\section{Molecular study}

Analyses of the individual markers show congruence within the nuclear and plastid markers, as well as congruence among the methods of analyses (Supplementary figures). However, the nuclear (Figure 1A) and plastid phylogenies (Figure 1B) had conflicting backbone topologies and are therefore presented separately. Regardless, there is strong support in both data sets for the tribe Cypereae with the Cyperus and Ficinia clades as sister (Figures S1, S2, S3, S4). In the plastid topology (Figure 1B), Afroscirpoides diverged first, then strongly supported sister clades comprising i) Erioscirpus sister to Scirpoides, and ii) a clade comprising Hellmuthia,

Dracoscirpoides, Isolepis and Ficinia. In the nuclear topology, there is a grade showing successive divergence starting with Erioscirpus, Afroscirpoides, Dracoscirpoides, Scirpoides, Hellmuthia, then Isolepis and Ficinia. In both analyses, there is strong support for the monophyly of the Dracoscirpoides, Hellmuthia and Scirpoides, but Isolepis is paraphyletic with Ficinia as one of the clades.

The position of Isolepis hemiuncialis and I. incomtula differed in the two analyses. These two species formed an early diverging grade leading to a polytyomy among core Isolepis in the plastid topology (Figure 1B), but were part of the I. marginata clade in the nuclear phylogeny (Figure 1A; Figure 2). On the other hand, I. marginata and allied species (I. antarctica, I. capensis, I. leucoloma and I. minuta) were consistently resolved as part of a clade including Ficinia eligulata and sister to the core Ficinia clade. The nuclear topology is better resolved, showing subclades in core Isolepis which coincide with current infrageneric groups, but these groups are not clearly discrenable in the plastid topology. In addition, the nuclear ITS alignment shows a three nucleotide insertion (ATA; position 1890-1892, Supplemental Information File Data S1), unique to the core Isolepis clade and lacking in the outgroup as well other Isolepis (I. hemiuncialis, I. incomtula, I. marginata and allies) and Ficinia.

\section{Morphological study}

Table 1 summarises the morphological diversity among genera in the ingroup. All Ficinia Clade taxa share the presence of Cyperus or a modified type (Ficinia) embryo. They are annuals or perennials; are mostly scapose, though multiple nodes are observed in Ficinia (e.g. F. trichodes (Schrad.) B.D.Jacks.); and have leaf blades well developed or reduced to a lobe, with or without 
200 ligule. The inflorescence is diverse (single terminal, e.g. I. ludwigii (Steud.) Kunth, Figure 3A; 201 capitate, e.g. F. ecklonea (Steud.) Nees, Figure 3I; pseudolateral, e.g. Afroscirpoides; to 202 anthelate, e.g. S. burkei (C.B.Clarke) Goetgh., Muasya \& D.A.Simpson). Glume arrangement is 203 predominantly spiral, with distichous arrangement in some species of Isolepis and Ficinia (e.g. I. 204 levynsiana Muasya \& D.A.Simpson, Figure 3B; F. distans C.B.Clarke). The flowers are bisexual 205 and occurring in most florets, but dioecy is observed in Afroscirpoides. While majority of taxa 206 lack perianth, these occur in Erioscirpus (large and plumose as seen in Eriophorum L.),

207

208

209

210

211

212

213

214

215

216

217

218

219

220

221

222

223

224

225

226

227

228

229

230

231

232

233

234

235

236

237

238

239

240

241

242

243

244

Dracoscirpoides (bristles) and Hellmuthia (scales). Nutlets are trigonous to oval in cross section, with the base extended to form a gynophore in the majority of Ficinia.

Species in the Isolepis and Ficinia clades vary in subtle morphological and ecological features (Table1; Figure 3). Isolepis hemiuncialis and I. incomtula are annual species, whose gross morphology and ecology is similar to annual species in the core Isolepis clade and $I$. marginata (and allies). Ficinia is unique in its ecology, frequently growing as perennial in dry habitats and unlike perennial Isolepis species that are restricted to wetlands. An additional feature, the presence of a gynophore is unique to Ficinia, eventhough several species (e.g. F. filiformis (Lam.) Schrad., F. trollii (Kük.) Muasya \& D.A.Simpson) lack this feature and vestigial gynophore occasionally occur in Isolepis marginata. Glume texture is chartaceous in Isolepis (including I. hemiuncialis and I. incomtula), whereas it is cartilaginous in Ficinia (including I. marginata and allies).

\section{Discussion}

This study has inferred the phylogeny of the Ficinia Clade using a large species sample ( $78 \%$ of species) and Sanger sequencing of nuclear and plastid markers. The patterns observed are similar to previous studies (Muasya et al., 2009a, b; Muasya and De Lange 2010; Hinchcliff \& Roalson, 2013; Spalink et al., 2016; Semmouri et al., 2019), confirming the monophyly of the smaller genera but recovering Ficinia to be nested in Isolepis. The backbone differs between the plastid and nuclear topology, especially relating to the position of Dracoscirpoides which is positioned between Afroscirpoides and Scirpoides (nuclear, Figure 1A) or between Hellmuthia and the Isolepis/Ficinia clade (plastid, Figure 1B). Similarly, these varied topologies have been observed in previous studies (e.g. Garcia-Madrid et al., 2015). As the majority of the deeper nodes in the Ficinia Clade are highly supported (PP above 0.95, Figure 1A, B), we suspect that the observed pattern is caused by evolutionary phenomena such as reticulate evolution (e.g. Pelser et al. 2010).

The phylogenetic position of Isolepis hemiuncialis and I. incomtula is unstable, shifting based on the markers analyzed. These taxa form a lineage (or grade) separate from the core Isolepis and Ficinia clades based on plastid data in this and previous studies (Garcia-Madrid et al., 2015; Spalink et al. 2016), and a similar pattern was observed in a combined plastid and nuclear analysis (rps16 \& ITS; Muasya \& De Lange, 2010). In addition, the nuclear markers differ in their placement of these samples, with ITS having a pattern similar to plastid markers (similarly observed in Figure S1, S2 of Garcia-Madrid et al., 2015), but ETS placing these species as part of clade with I. marginata (similarly observed in Figure S3, S4 of García-Madrid et al., 2015). In the combined nuclear matrix, these two species are part of the I. marginata clade. In contrast, I. marginata (and allied species) have been consistently observed to be forming a clade sister to core Ficinia in separate and combined analyses, and these species are in same clade with $F$. eligulata Gordon-Gray ex Muasya from the Drakensberg Mountain.

Peer) reviewing PDF | (2020:08:52103:1:1:NEW 9 Dec 2020) 
245
A unique 3 base-pair insertion in ITS2 further supports the uniqueness of the core Isolepis. This insertion is missing in I. hemiuncialis, I. incomtula as well as the species in the $I$. marginata clade, and can therefore be used as a synapomorphy for the core Isolepis clade. Similar use of indels, located at the 5.8S gene of the nuclear ribosomal DNA, as synapomorphies has been suggested for the Cypereae (Yano et al., 2012) and Cyperaceae (Starr et al., 2007).

A number of the genera in the ingroup can be distinguished unambiguously based on one or few characters (Table 1). The presence and type perianth segments, even though perhaps arising independently, are unique in Dracoscirpoides (scabrid bristles; Muasya et al., 2012), Erioscirpus (cotton-like bristles; Yano et al., 2012) and in Hellmuthia (scale-like; Vrijdaghs et al., 2006). Among the taxa lacking perianth segments, Afroscirpoides and Scirpoides have densely tufted culms which have reduced leaf blades ( $>5 \mathrm{~mm}$, but some Scirpoides have well developed leaf blades), with the former having dioecious individuals whereas the later has bisexual florets. Ficinia is most similar in gross morphology and ecology to Afroscirpoides and Scirpoides, diagnosed by the presence of a cupular disk (gynophore; Vrijdaghs et al., 2005) at the base of the nutlets (except in several species where the trait is lost; Muasya et al., 2014). Isolepis is most similar to Ficinia, sharing presence of bisexual florets and glumes with well defined parallel veins, but differing in Isolepis lacking the gynophore. The glume texture appears to offer additional separation, being chartaceous to hyaline (herbaceous; Muasya \& Simpson, 2002) in Isolepis but cartilaginous (or coriaceious) in Ficinia.

Generic boundaries within Isolepis and Ficinia have been noted as problematic. Eleogiton, still recognized as distinct in some floras (e.g. Germany, Kadereit et al., 2016) based on possessing multiple internodes and peduncle termination in a single terminal spikelet, is confirmed to be a clade in Isolepis (subgenus Fluitantes; Muasya et al., 2001; Muasya \& Simpson, 2002). In Ficinia, Sickmania Nees has been previously recognized based on a capitate inflorescence with multiple leaf-like bracts ( F. radiata) whereas Desmoschoenus has primary bracts adnate to axis and covering congested spikelets) (Goetghebeur, 1998). The phylogenetic inference showing I. maginata and other annual species that lack a gynophore being closer to Ficinia further blurs the generic boundaries.

Cyperaceae has experienced shifting generic classification in the last two decades. The paradigm shift to recognize monophyletic genera (Humphries \& Linder, 2009) accompanied by the use of DNA sequence data have enabled disentangling phylogenetic relatedness of taxa obscured by extreme morphological modification. Several highly diversified lineages appear to have been split into genera based on one of few characters, at times such characters arising independently. This phenomenon was epitomized Cyperus, now recognized as a single genus (Larridon et al. 2011a, b, 2013, 2014; Bauters et al. 2014), where 13 segregate genera were diagnosed based on morphology of reproductive structures (spikelet size and organization, nutlet orientation, style branching; Muasya et al., 2009a). This study supports a further refinement within the Cypereae, recognizing the core Isolepis and an enlarged Ficinia at generic level.

We speculate that the Ficinia clade evolved in southern Africa, given that majority of lineages and species occur in the region. Diversification in Isolepis and Ficinia has occurred since the Miocene (Besnard et al., 2009), perhaps ecologically driven by aridification associated with onset of the Mediterranean climate (Linder \& Verboom, 2015), where emerging traits include annual life form, colonization of permanently wet habitats, sprouting regeneration driven by the frequent fires in sclerophyllous habitats, and ant dispersal of seeds (gynophore in Ficinia; Bond \& Slingsby, 1983). Within southern Africa, the Ficinia Clade members are predominantly occurring in the Greater Cape Flora and exhibit the typical diversification pattern whereby

Peer] reviewing PDF | (2020:08:52103:1:1:NEW 9 Dec 2020) 
291 lineages in the Fynbos are older than those in the Succulent Karoo biome (Verboom et al., 2009).

292 Dispersal out of the Cape appears to be predominantly to other similar habitats, especially in

293 Mediterranean Eurasia (Erioscirpus, Isolepis, Scirpoides), within temperate zones of high

294 mountains in tropical Africa (Dracoscirpoides, Ficinia, Isolepis, Scirpoides) and austral

295 temperate areas (Ficinia, Isolepis). Dispersal to Australasia in Isolepis has been accompanied by

296 hybridization in Isolepis (Ito et al., 2016).

297

298

299

300

301

302

303

304

305

306

307

308

309

310

311

312

313

314

315

316

317

318

319

320

321

322

323

324

325

326

327

328

329

330

331

332

333

\section{Taxonomic treatment}

The current generic classification is supported for the smaller genera (Afroscirpoides, Dracoscirpoides, Erioscirpus, Hellmuthia, Scirpoides). However, Isolepis is paraphyletic as Ficinia is one of its clades as well as Ficinia is paraphyletic if I. marginata and allies are excluded. We acknowledge the conflicting topology between the nuclear and plastid phylogenies, particularly regarding the position of I. hemiuncialis and I. incomtula, opting to follow the nuclear phylogeny. We take a phragmatic approach, to recognize clades that will minimize nomenclatural changes, by adopting a classification framework based on the nuclear phylogeny (Figure 2). We therefore recognize an expanded concept of Ficinia, to include annual species with mostly cartilaginous glumes and lacking a gynophore (occasionally a gynophore is observed among Australian I. marginata, see Figure 3F). As a consequence, Isolepis is now considered in a narrower concept which encompasis the core Isolepis and excludes the seven annual species placed within the Ficinia clade (I. antactica, I. capensis, I. hemiuncialis, I. incomtula, I. leucoloma, I. marginata and I. minuta). Subclades within Isolepis can be recognized as infrageneric groups, recognizing four subgenera where 3 are similar to classification by Muasya \& Simpson (2002) but elevating sect. Proliferae to subgeneric rank. In Ficinia, previous infrageneric groups (Clarke 1897-98; Pfeiffer, 1921) are not supported, but the two clades each with subclades could form basis for future infrageneric classification. Formal taxonomic changes are made here, but we note the need of a comprehensive taxonomic revision of Ficinia.

\section{Key to the species of Ficinia clade genera}

1 Plants perennial or annual; perianth segements absent. ..............................................4

1 Plants perennial; perianth segements present.............................................................2

2 Perianth segment cotton-like, restricted to Asia ................................................ Erioscirpus

2 Perianth segment bristle or scale-like; restricted to southern Africa .................................... 3

3 Slender plants, culm $<4$ mm diameter; perianth bristle-like; in Drakensberg and surrounding areas.

2. Dracoscirpoides

3 Robust plant, culm $>5 \mathrm{~mm}$ diameter; perianth scale-like; in Cape area. .......... 3. Hellmuthia

4 Perennial habit; inflorescence in globose clusters of over 10 spikelets; nutlet lacking a

gynophore; embryo Cyperus-type.

4 Perennial or annual habit; inflorescence in mostly clusters mostly of under 10 spikelets; nutlet with or without a gynophore; embryo Cyperus- or Ficinia-type

5 Plants leafless; inflorescence pseudolateral, dioecious.

4. Afroscirpoides.

5 Plants leafless or well developed blades; inflorescence with bisexual flowers, pseudolateral to anthelate 5. Scirpoides.

334

6 Glumes chartaceous, nutlet lacking gynophore. 6. Isolepis.

Peer) reviewing PDF | (2020:08:52103:1:1:NEW 9 Dec 2020) 
335

336

337

338

339

340

341

342

343

344

345

346

347

348

349

350

351

352

353

354

355

356

357

358

359

360

361

362

363

364

365

366

367

368

369

370

371

372

373

374

375

376

377

378

379

380

6 Glumes cartilaginous, nutlet mostly bearing gynophore.

7. Ficinia

1. Erioscirpus Palla, Bot. Zeitung (Berlin) 54: 151 (1896). Type species - Erioscirpus comosus (Wall.) Palla, designated here.

Two species of perennial hemicryptophytes, diagnosed on presence of cotton-like perianth. Taxonomic revision as part of regional flora, e.g. Flora of Pakistan (http://www.tropicos.org/Project/Pakistan).

Distributed in Asia, from Iran to China, occurring in shallow soil and rocky crevices, at $700-2300 \mathrm{~m}$.

2. Dracoscirpoides Muasya, S. African J. Bot. 78: 108 (2012). Type species - Dracoscirpoides falsa (C.B.Clarke) Muasya.

Three species of perennial hemicryptophytes or rhizomatous geophytes, taxonomy revised in Muasya et al. 2012.

Restricted to southern Africa, occurring in montane grasslands.

3. Hellmuthia Steud., Syn. Pl. Glumac. 2: 90 (1855). Type species - Hellmuthia membranacea (Thunb.) R.W.Haines \& Lye.

Monotypic, hemicryptophytes or rhizomatous geophytes, diagnosed by presence of scalelike perianth. Taxonomic studies in local flora (e.g. Archer \& Muasya, 2012).

Restricted to South Africa, occurring coastal areas in calcareous sandy soils in the Cape Flora.

4. Afroscirpoides García-Madr. \& Muasya, Taxon 64: 698 (2015). Type species - Afroscirpoides dioeca (Kunth) García-Madr.

Monotypic, densely tufted hemicryptophytes or rhizomatous geophytes, diagnosed by dioecious flowers borne in dense globose inflorescences whose bract terminates in a sharppointed tip.

Restricted to southern Africa, occurring in seepages and streambeds in brackish habitats.

5. Scirpoides Ség., Pl. Veron. 3: 73 (1754). Type species - Scirpoides holoschoenus (L.) Soják, designated here.

Four species recognized in Govaerts et al. (2020), but two additional species segregated from the widespread S. holoschoenus by García-Madrid et al. (2015).

Widespread in Mediterannean habitat in Mexico, Canary Is. through northern Africa and Eurasia to W. Himalaya, South Africa.).

6. Isolepis R.Br., Prodr. Fl. Nov. Holland.: 221 (1810). Type species - Isolepis setacea (L.)

R.Br.

About 70 species recognized here, after moving seven species to Ficinia. Nearly a third of species are therophytes, rest are hemicryptophytes or rhizomatous geophytes. Most recent and comprehensive taxonomic revision in Muasya \& Simpson (2002).

Nearly cosmopolitan distribution, with highest species densities in austral temperate southern Africa and Australasia. 
381

382

383

384

385

386

387

388

389

390

391

392

393

394

395

396

397

398

399

400

401

402

403

404

405

406

407

408

409

410

411

412

413

414

415

416

417

418

419

420

421

422

7. Ficinia Schrad., Commentat. Soc. Regiae Sci. Gott. Recent. 7: 143 (1832). Type species Ficinia gracilis Schrad.

About 90 species are recognized here, including the annual species transferred from Isolepis. Majority of species are perennial hemicryptophytes or rhizomatous geophytes, adapted to survive frequest fires in the Fynbos biomes, but also few annual and pyrophytic short-lived perrenials. The most comprehensive taxonomic study of Ficinia was part of the Flora Capensis (Clarke, 1897-98) and recent synopsis of the Cape Flora (Archer \& Muasya, 2012). Ongoing studies reveal existence of undescribed species and the Ficinia is among the highest priority Cypeaceae for taxonomic revision in southern Africa.

Predominantly occurring in southern Africa in the Cape Flora and extending into montane areas of tropical Africa. Two species occur in Australasia, among which F. nodosa is nearly circumpolar.

\section{Species transferred from Isolepis to Ficinia in this study:}

The annual Isolepis species forming a clade sister to F. eligulata (Figure 2) are here transferred into Ficinia.

\section{Ficinia capensis (Muasya) Muasya, comb. nov. \\ Isolepis capensis Muasya, Kew Bull. 57: 305 (2002). [basionym] \\ Ficinia heminucialis (C.B.Clarke) Muasya, comb. nov.}

Scirpus hemiuncialis C.B.Clarke in É.A.J.de Wildeman, Pl. Nov. Horti Then. 1: 23 (1904).

[basionym]

Isolepis hemiuncialis (C.B.Clarke) J.Raynal, Adansonia, n.s., 17: 55 (1977).

Ficinia incomtula (Nees) Muasya, comb. nov.

Isolepis incomtula Nees, Linnaea 10: 154 (1835). [basionym]

Ficinia leucoloma (Nees) Muasya, comb. nov.

Cyperus leucoloma Nees, Linnaea 10: 133 (1835). [basionym]

Isolepis leucoloma (Nees) C.Archer, Bothalia 28: 42 (1998).

Ficinia marginata (Thunb.) Fourc., Trans. Roy. Soc. South Africa 21: 76 (1932).

Scirpus marginatus Thunb., Prodr. Pl. Cap.: 17 (1794). [basionym].

Isolepis marginata (Thunb.) A.Dietr., Sp. P1. 2: 110 (1833).

There appears to be continuity in the number of spikelets per inflorescence, with materials at extreme ends recognized as I. marginata versus I. antarctica. We retain the two taxa as a single species, Ficinia marginata, and refrain from making a new combination pending a detailed taxonomic study of the complex.

Ficinia minuta (Turrill) Muasya, comb. nov.

Scirpus minutus Turrill, Bull. Misc. Inform. Kew 1925: 69 (1925). [basionym] 
423

424

425

426

427

428

429

430

431

432

433

434

435

436

437

438

439

440

441

442

443

444

445

446

447

448

449

450

451

452

453

454

455

456

457

458

459

460

461

462

463

464

Isolepis minuta (Turrill) J.Raynal, Adansonia, n.s., 17: 56 (1977)

\section{Conclusions}

This study aimed to establish the phylogenetic position of contentious annual species currently placed in Isolepis and to test the monophyly of the genera. All the other smaller genera in the Ficinia clade (Afroscirpoides, Dracoscirpoides, Erioscirpus, Hellmuthia and Scirpoides) are monophyletic. There is unambiguous placement of I. marginata and allies (I. antarctica, I. capensis, I. leucoloma and I. minuta) as a clade within Ficinia and not part of the core Isolepis clade. Inclusion of I. hemiuncialis and I. incomtula into a clade including I. marginata is supported by the nuclear phylogeny, but these taxa are placed in a grade outside the core Isolepis clade. We propose the reclassification of these Isolepis species, resolved outside the core Isolepis, as species within Ficinia. The proposed classification will add taxa lacking the gynophore, the currently used diagnostic character for Ficinia, with the core Isolepis diagnosed by a combination of morphology (e.g. chartaceous glumes, no gynophore) and a unique indel in ITS.

\section{Acknowledgements}

We thank J-A Viljoen, R. Skelton and S. Wiswedel for assistance with laboratory work.

\section{References}

Archer C, Muasya AM. 2012. Cyperaceae. In: Manning J, Goldblatt P. (eds.), Plants of the Greater Cape Floristic Region 1: The Core Cape Flora. Strelitzia 29: 84-96. Pretoria: South Africa National Biodiversity Institute.

Barrett RL, Wilson KL, Bruhl JJ. 2019. Anthelepis, a new genus for four mainly tropical species of Cyperaceae from Australia, New Caledonia and South-East Asia. Australian Systematic Botany 32: 269-289.

Bauters K, Larridon I, Reynders M, Asselman P, Vrijdaghs A, Muasya AM, Simpson DA, Goetghebeur P. 2014 A new classification for Lipocarpha and Volkiella as infrageneric taxa of Cyperus s.I. (Cypereae, Cyperoideae, Cyperaceae): Insights from species tree reconstruction supplemented with morphological and floral developmental data.

Phytotaxa 166: 1-32. https://www.biotaxa.org/Phytotaxa/article/view/phytotaxa.166.1.1

Besnard G, Muasya AM, Russier F, Roalson EH, Salamin N, Christin P-A. 2009. Phylogenomics of $\mathrm{C} 4$ photosynthesis in sedges (Cyperaceae): multiple appearances and genetic convergence. Molecular Biology and Evolution 26:1909-1919.

Bond WJ, Slingsby P. 1983 Seed dispersal by ants in shrublands of the Cape Province and its evolutionary implications. South African Journal of Science 79: 231-233.

Browning J, Gordon-Gray KD. 2011. Studies in Cyperaceae in South Africa 43: Scirpoides varius Browning-a new name for Scirpus varius Boeck. ex. C.B.Clarke. South African Journal of Botany 77: 506-508.

Clarke 1897-98. Ficinia. In: Thiselton-Dyer WT (Ed.), Flora Capensis: Being a Systematic Description of the Plants of the Cape Colony, Caffraria, \& Port Natal. Lovell Reeve \& Co., Ltd., London, United Kingdom. 
465

466

467

468

469

470

471

472

473

474

475

476

477

478

479

480

481

482

483

484

485

486

487

488

489

490

491

492

493

494

495

496

497

498

499

500

501

502

503

504

505

506

507

508
Elliott TL, Muasya AM. 2017. Taxonomic realignment in the southern African Tetraria (Cyperaceae, tribe Schoeneae; Schoenus clade). South African Journal of Botany 112: 354-360.

García-Madrid AS, Muasya AM, Álvarez I, Cantó P, Molina JA. 2015. Towards resolving phylogenetic relationships in the Ficinia clade and description of the new genus Afroscirpoides (Cyperaceae: Cypereae). Taxon 64: 688-702.

Global Carex Group [GCG]. 2015. Making Carex monophyletic (Cyperaceae, tribe Cariceae): a new broader circumscription. Botanical Journal of the Linnean Society 179: 1-42.

Goetghebeur P. 1986. Genera Cyperacearum. Een bijdrage tot de kennis van de morfologie, systematiek en fylogenese van de Cyperaceae-genera. Unpublished D. Phil. Thesis, Ghent University, Belgium.

Goetghebeur P. 1998. Cyperaceae. In: Kubitzki K ed. The families and genera of vascular plants 4. Berlin: Springer-Verlag. 141-190.

Govaerts R, Jiménez-Mejías P, Koopman J, Simpson DA, Goetghebeur P, Wilson KL, Egorova T. Bruhl JJ. 2020. World checklist of Selected Plant Families. Cyperaceae. The Board of Trustees of the Royal Botanic Gardens, Kew. Published on the Internet; http://www.kew.org/wcsp/monocots/ accessed 01.06.2020.

Hinchliff CE, Roalson EH. 2013. Using supermatrices for phylogenetic inquiry: an example using the sedges. Systematic Biology 62: 205-219.

Humphreys AM, Linder HP. 2009. Concept versus data in delimitation of plant genera. Taxon 58: 1054-1074.

Ito Y, Viljoen J-A, Tanaka N, Yano O, Muasya AM. 2016. Phylogeny of Isolepis (Cyperaceae) revisited: non-monophyletic nature of $I$. fluitans sensu lato and resurrection of $I$. lenticularis. Plant Systematics and Evolution 302: 231-238.

Kadereit JW, Albach DC, Ehrendorfer F, Galbany-Casals M, Garcia-Jacas N, Gehrke B, Kadereit G, Kilian N, Klein JT, Koch MA, Kropf M, Oberprieler C, Pirie MD, Ritz CM, Röser M, Spalik K, Susanna A, Weigend M, Welk E, Wesche K, Zhang L-B, Dillenberger MS. 2016: Which changes are needed to render all genera of the German flora monophyletic? - Willdenowia 46: 39 - 91. doi: http://dx.doi.org/10.3372/wi.46.46105

Katoh K, Asimenos G, Toh H. 2009. Multiple alignment of DNA sequences with MAFFT. Methods in Molecular Biology 537:39-64 DOI 10.1007/978-1-59745-251-9_3.

Katoh K, Standley DM. 2013. MAFFT multiple sequence alignment software version 7: improvements in performance and usability. Molecular Biology and Evolution 30:772780 DOI 10.1093/molbev/mst010.

Kearse M, Moir R, Wilson A, Stones-Haves S, Cheung M, Sturrock S, Buxton S, Cooper A, Markowitz S, Duran C, Thierer T, Ashton B, Meintjes P, Drummond A. 2012. Geneious Basic: an integrated and extendable desktop software platform for the organization and analysis of sequence data. Bioinformatics 28:1647-1649 DOI 10.1093/bioinformatics/bts199.

Lanfear R, Calcott B, Ho SYW, Guindon S. 2012. PartitionFinder: combined selection of partitioning schemes and substitution models for phylogenetic analyses. Molecular Biology and Evolution 29:1695-1701 DOI 10.1093/molbev/mss020.

Larridon I, Reynders M, Huygh W, Bauters K, Van de Putte K, Muasya AM, Boeckx P, Simpson DA, Vrijdaghs A, Goetghebeur P. 2011a. Affinities in C3 Cyperus lineages (Cyperaceae) 
509

510

511

512

513

514

515

516

517

518

519

520

521

522

523

524

525

526

527

528

529

530

531

532

533

534

535

536

537

538

539

540

541

542

543

544

545

546

547

548

549

550

551 revealed using molecular phylogenetic data and carbon isotope analysis. Botanical Journal of the Linnean Society 167(1): 19-46. https://doi.org/10.1111/j.10958339.2011.01160.x

Larridon I, Reynders M, Huygh W, Bauters K, Vrijdaghs A, Leroux O, Muasya AM, Simpson DA, Goetghebeur P. 2011b. Taxonomic changes in C3 Cyperus (Cyperaceae) supported by molecular phylogenetic data, morphology, embryology, ontogeny and anatomy. Plant Ecology and Evolution 144(3): 327-356. https://doi.org/10.5091/plecevo.2011.653

Larridon I, Bauters K, Reynders M, Huygh W, Muasya AM, Simpson DA, Goetghebeur P. 2013. Towards a new classification of the giant paraphyletic genus Cyperus (Cyperaceae): phylogenetic relationships and generic delimitation in C4 Cyperus. Botanical Journal of the Linnean Society 172(1): 106-126. https://doi.org/10.1111/boj.12020

Larridon I, Bauters K, Reynders M, Huygh W, Goetghebeur P. 2014. Taxonomic changes in C4 Cyperus (Cypereae, Cyperoideae, Cyperaceae): combining the sedge genera Ascolepis, Kyllinga and Pycreus into Cyperus s.I. Phytotaxa 166(1): 33-48. https://doi.org/10.11646/phytotaxa.166.1.2

Larridon I, Semmouri I, Bauters K, Viljoen JA, Prychid CJ, Muasya AM, Bruhl JJ, Wilson KA, Goetghebeur P. 2018a. Molecular phylogenetics of the genus Costularia (Schoeneae, Cyperaceae) reveals multiple distinct evolutionary lineages. Molecular Phylogenetics and Evolution 126:196-209 DOI 10.1016/j.ympev.2018.04.016.

Larridon I, Verboom GA, Muasya AM. 2018b. Revised delimitation of the genus Tetraria, nom. cons. prop. (Cyperaceae, tribe Schoeneae, Tricostularia clade). South African Journal of Botany 118: 18-22.

Larridon I, Spalink D, Jiménez-Mejías P, Márquez-Corro JI, Martin-Bravo S, Muasya AM, Escudero M. Accepted. The evolutionary history of sedges in Madagascar. Journal of Biogeography JBI-20-0212.

Linder HP, Verboom GA. 2015. The evolution of regional species richness: the history of the southern African flora. Annual Review of Ecology, Evolution, and Systematics 46: 393412.

Linnaeus C. 1753. Schoenus. Species Plantarum: exhibentes Plantas Rite Cognitas, Ad Genera Relatas, Cum Differentiis Specificis, Nominibus Trivialibus, Synonymis Selectis, Locis Natalibus, Secundum Systema Sexuale Digestas. Sweden.

Miller MA, Pfeiffer W, Schwartz T. 2011. The CIPRES science gateway: a community resource for phylogenetic analyses. Proceedings of the 2011 TeraGrid Conference: Extreme Digital Discovery: 41. ACM, New York DOI 10.1145/2016741.2016785.

Muasya AM, Simpson DA, Goetghebeur P. 2000. New combinations in Trichophorum, Scirpoides and Ficinia (Cyperaceae). Novon 10: 132-133

Muasya AM, Simpson DA, Chase MW, Culham A. 2001. A phylogeny of Isolepis (Cyperaceae) inferred using plastid rbcL and trnL-F sequence data. Systematic Botany 26: 342-353.

Muasya AM, Simpson DA. 2002. A monograph of the genus Isolepis R.Br. (Cyperaceae). Kew Bulletin 57: 257-362.

Muasya AM, Vrijdaghs A, Simpson DA, Chase MW, Goetghebeur P, Smets E. 2009a. What is a Genus in Cypereae: Phylogeny, Character Homology Assessment and Generic Circumscription in Cypereae. Botanical Review 75: 52-66.

Peer] reviewing PDF | (2020:08:52103:1:1:NEW 9 Dec 2020) 
552

553

554

555

556

557

558

559

560

561

562

563

564

565

566

567

568

569

570

571

572

573

574

575

576

577

578

579

580

581

582

583

584

585

586

587

588

589

590

591

592

593

594

595

Muasya AM, Simpson DA, Verboom GA, Goetghebeur P, Naczi RFC, Chase MW, Smets E. 2009b. Phylogeny of Cyperaceae based on DNA sequence data: current progress and future prospects. Botanical Review 75: 2-21.

Muasya AM, de Lange P. 2010. Ficinia spiralis (Cyperaceae) a new genus and combination for Desmoschoenus spiralis. New Zealand Journal of Botany 48: 31-39.

Muasya AM, Reynders M, Goetghebeur P, Simpson DA, Vrijdaghs A. 2012. Dracoscirpoides (Cyperaceae) - a new genus from Southern Africa, its taxonomy and floral ontogeny. South African Journal of Botany 78: 104-115.

Muasya AM, Viljoen J-A, Dludlu MN, Demissew S. 2014. Phylogenetic position of Cyperus clandestinus (Cypereae, Cyperaceae) clarified by morphological and molecular evidence. Nordic Journal of Botany 32: 106-114.

Müller J, Müller K, Neinhuis C, Quandt D. 2010. PhyDEPhylogenetic Data Editor, version 0.9971. Available at http://www.phyde.de/ (accessed on 10 January 2016).

Pelser PB, Kennedy AH, Tepe EJ, Shidler JB, Nordenstam B, Kadereit JW, Watson LE. 2010. Patterns and causes of incongruence between plastid and nuclear Senecioneae (Asteraceae) phylogenies. American Journal of Botany 97: 856-873.

Pereira-Silva L, Trevisan R, Rodrigues AC, Larridon I. 2020. Combining the small South American genus Androtrichum in Cyperus (Cyperaceae). Plant Ecology and Evolution 153: 446-454..

Pfeiffer H. 1921. Revision der Gattung Ficinia Schrad. Druck und Verlag E. Gerst, Bremen, pp. $1-62$.

Rambaut A, Drummond AJ. 2007. Tracer, a MCMC Trace Analysis Tool. Institute of Evolutionary Biology, University of Edinburgh. http://beast.bio.ed.ac.uk/.

Reid CS, Doyle VP, Carter JR, Vargas-Rodriguez Y, Urbatsch LE. 2017. Molecular systematics of targeted flat sedges (Cyperus, Cyperaceae) of the Americas. Plant Ecology and Evolution 150: 343-357.

Ronquist F, Teslenko M, van der Mark P, Ayres DL, Darling A, Hohna S, Larget B, Liu L, Suchard MA, Huelsenbeck JP. 2012. MrBayes 3.2: Efficient Bayesian phylogenetic inference and model choice across a large model space. Systematic Biology 61:539-542 DOI 10.1093/sysbio/sys029.

Semmouri I, Bauters K, Léveillé-Bourret E, Starr JR, Goetghebeur P, Larridon I. 2019. The phylogeny and systematics of Cyperaceae, the evolution and importance of embryo morphology. Botanical Review 85: 1-39. DOI 10.1007/s12229-018-9202-0.

Spalink D, Drew BT, Pace MC, Zaborsky JG, Starr JR, Cameron KM, Givnish TJ, Sytsma KJ. 2016. Biogeography of the cosmopolitan sedges (Cyperaceae) and the area-richness correlation in plants. Journal of Biogeography 43: 1893-1904.

Stamatakis A. 2014. RAxML Version 8: a tool for phylogenetic analysis and post-analysis of large phylogenies. Bioinformatics 30:1312-1313 DOI 10.1093/bioinformatics/btu033.

Starr JR, Harris SA, Simpson DA. 2003. Potential of the 5' and 3' ends of the Intergenic Spacer (IGS) of rDNA in the Cyperaceae: new sequences for lower level phylogenies in sedges with an example from Uncinia Pers. International Journal of Plant Sciences 164, 213 227.

Stöver BC, Müller KF. 2010. TreeGraph 2: combining and visualizing evidence from different phylogenetic analyses. BMC Bioinformatics 11:7 DOI 10.1186/1471-2105-11-7.

Peer] reviewing PDF | (2020:08:52103:1:1:NEW 9 Dec 2020) 
596 Thiers B, continuously updated. Index herbariorum. Available at

$597 \quad$ http://sweetgum.nybg.org/science/ih/ (accessed on 30 July 2020).

598

Van der Veken P. 1965. Contribution à l'embryographie systématique des Cyperaceae-

$599 \quad$ Cyperoideae. Bulletin du Jardin Botanique de l'État à Bruxelles 35: 285-354.

600 Verboom GA, Archibald JK, Bakker FT, Bellstedt DU, Conrad F, Dreyer LL, Forest F, Galley C,

601

602

603

604

605

606

607

608

609

610

611 Goldblatt P, Henning JF, Mummenhoff K, Linder HP, Muasya AM, Oberlander KC, Savolainen V, Snijman DA, van der Niet T, Nowell TL. 2009. Origin and diversification of

612 the Greater Cape flora: Ancient species repository, hot-bed of recent radiation, or both? Molecular Phylogenetics \& Evolution 51: 44-53.

Vrijdaghs A, Goetghebeur P, Muasya AM, Caris P, Smets E. 2005. Floral ontogeny in Ficinia Schrad. and Isolepis R.Br. (Cyperaceae), with focus on the nature and origin of the gynophore. Annals of Botany 96: 1247-1262.

Vrijdaghs A, Goetghebeur P, Smets E, Muasya AM. 2006. The floral scales in Hellmuthia (Cyperaceae, Cyperoideae) and Paramapania (Cyperaceae, Mapanioideae): an ontogenetic study. Annals of Botany 98: 619-630.

Yano O, Ikeda H, Watson M F, Rajbhandari K R, Jin X-F, Hoshino T, Muasya AM \& Ohba H. 2012. Phylogenetic position of the Himalayan genus Erioscirpus (Cyperaceae) inferred

613 from DNA sequence data. Botanical Journal of the Linnean Society 170: 1-11. 


\section{Table $\mathbf{1}$ (on next page)}

Comparison of genera in the Ficinia clade, reflecting the revised classification. 


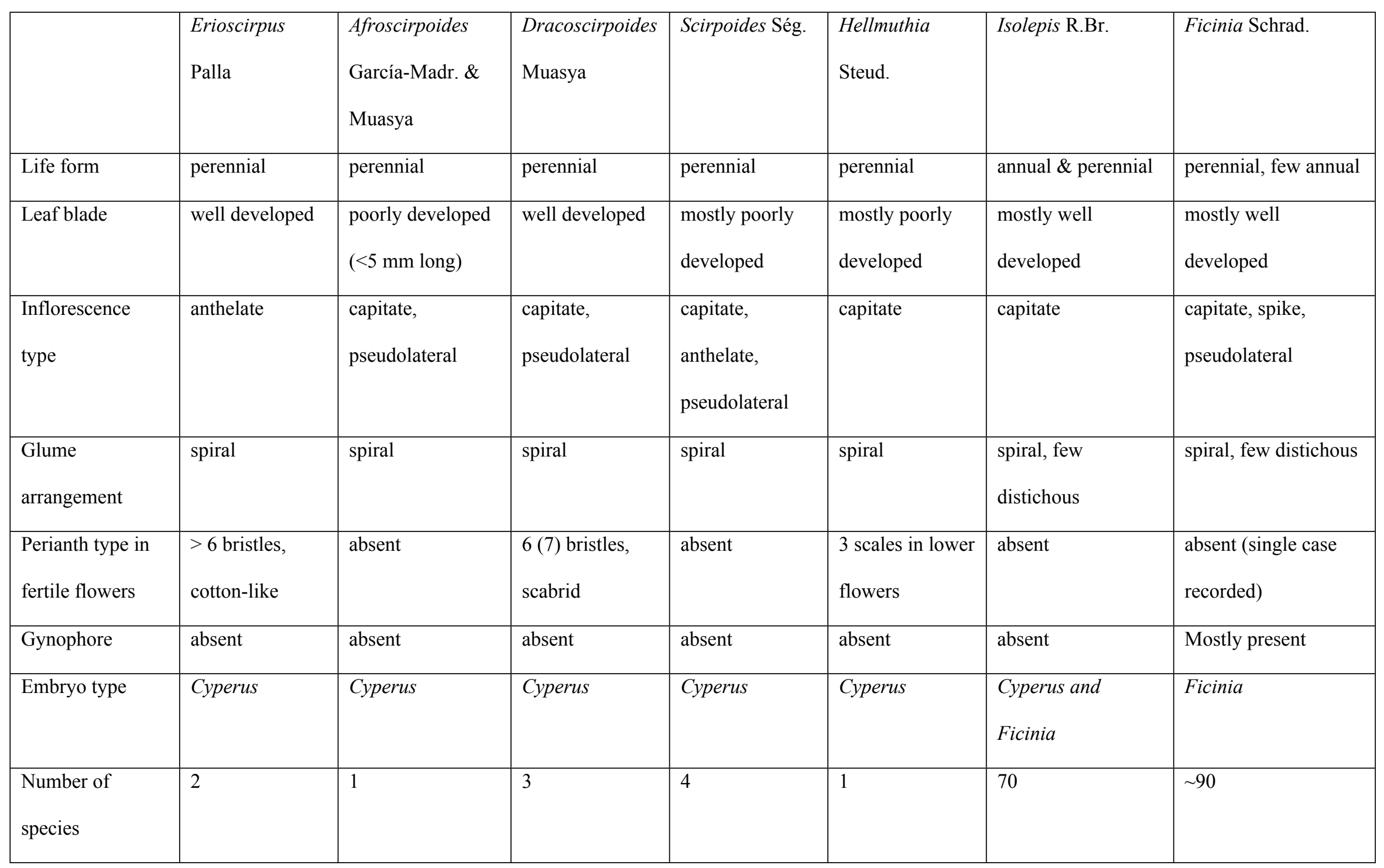




\begin{tabular}{|l|l|l|l|l|l|l|l|}
\hline Distribution & Asia & Southern Africa & Southern Africa & Southern Africa, & Southern Africa & Southern \& \\
& & & & Eurasia, & Tropical Africa, & Africa, Australasia, \\
(Cape) & Americas & & Australasia, \\
circumpolar & Europe, Americas, & \\
\hline
\end{tabular}


Figure 1

The majority-rule consensus Bayesian Inference of the Ficinia Clade, showing posterior probabilities at nodes, based on MrBayes analyses. A) concatenated nuclear, B) concatenated plastid DNA sequence data. 


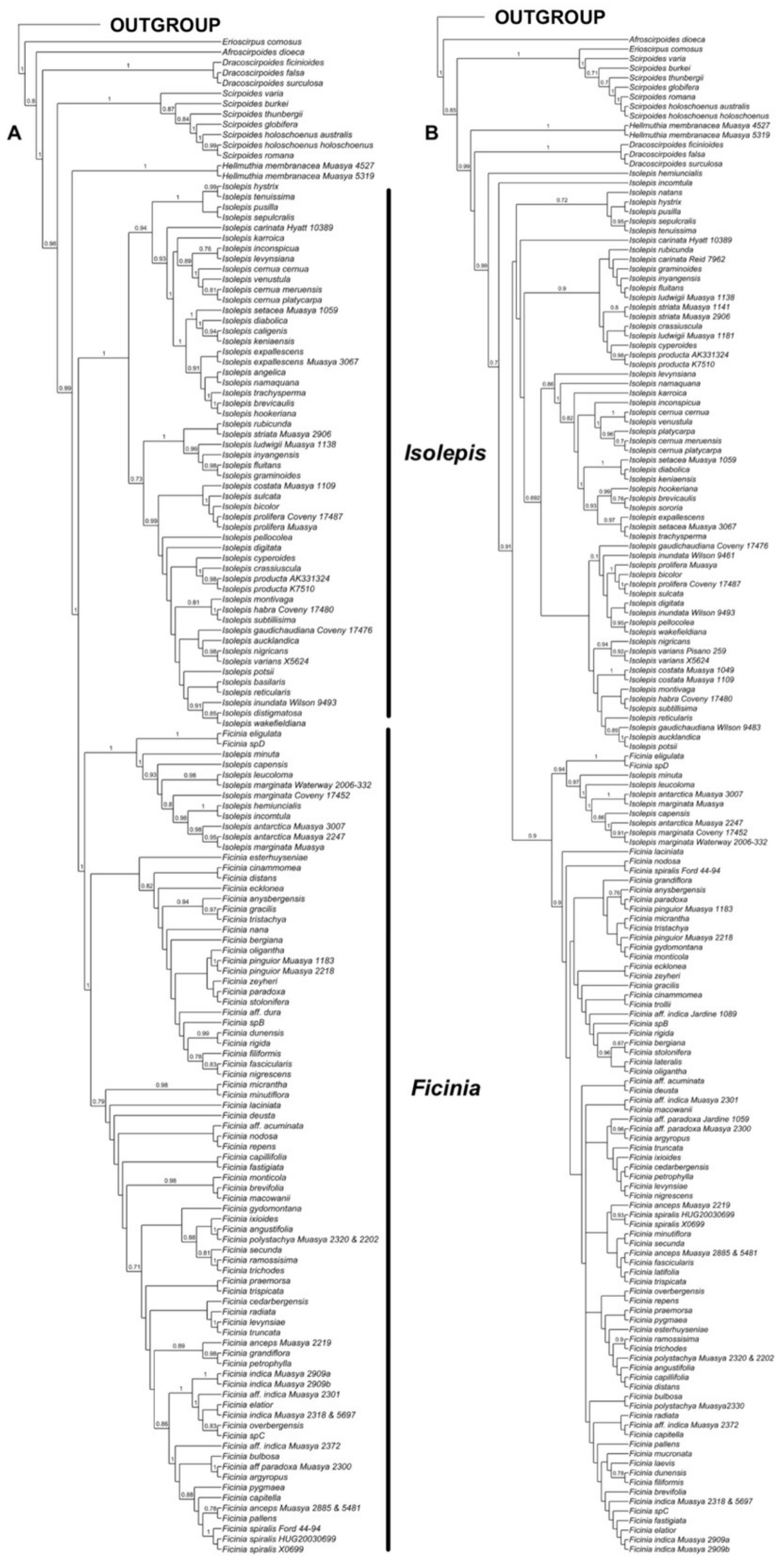


Figure 2

A simplified majority-rule consensus Bayesian Inference of the ingroup based on the concatenated nuclear DNA sequence data

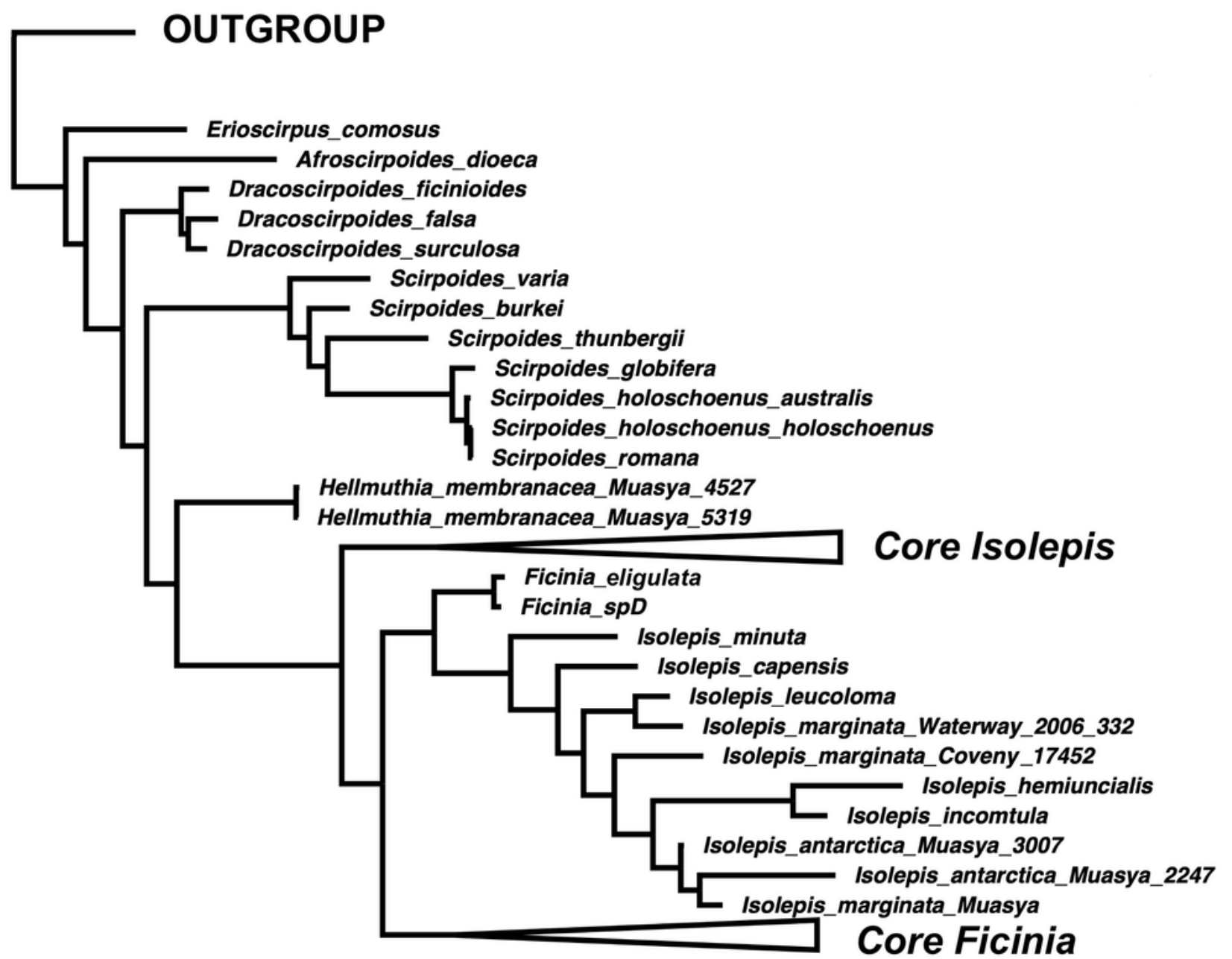


Figure 3

Morphological diversity in the Ficinia Clade.

(A) I. Iudwigii (Schlechter 1821 BOL); (B) I. levynsiana (Muasya 2274 BOL); (C) I. hemiuncialis (Muasya et al. 6040 BOL); (D) I. incomtula (BOL6370); (E) I. leucoloma (Levyns 7618 BOL); (F-G) I. marginata (Verboom 1241 BOL); (G) I. marginata (in situ); (I) F. ecklonea (Muasya \& Stirton $3215 \mathrm{BOL}$ ). Images of the inflorescences were made using a Leica S9i and habit photograph made by Muthama Muasya. 

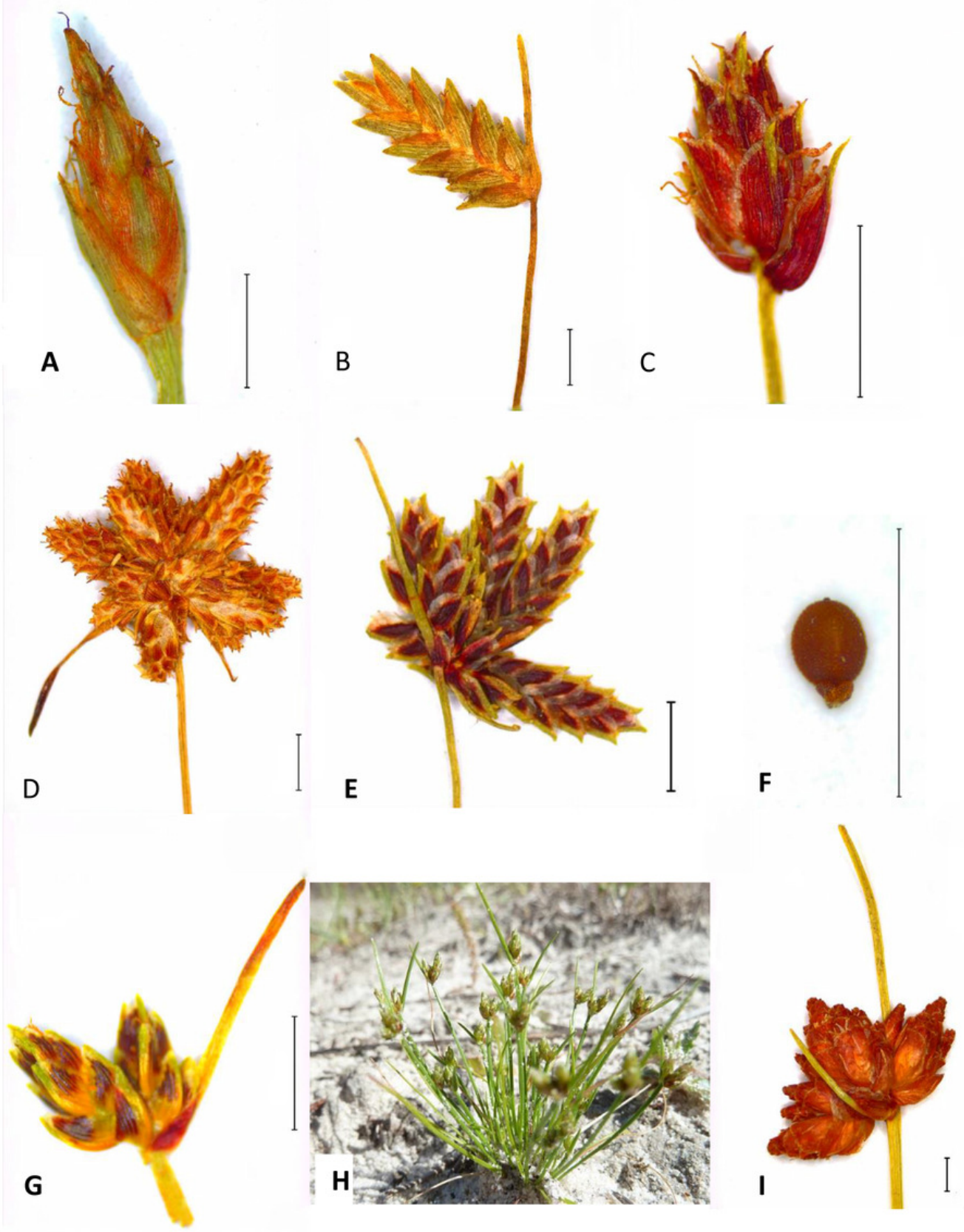